Volume 1, Nomor 2 Oktober 2019

ISSN : 2656-9639 (Cetak)

ISSN : 2684-9046 (Online)

\title{
CIVIC VIRTUE DALAM RANGKA MEWUJUDKAN PEMILU HARMONI DAN BERKEADILAN
}

\author{
I Putu Windu Mertha Sujana \\ Program Studi PPKn \\ Jurusan Hukum dan Kewarganegaraan \\ Fakultas Hukum dan Ilmu Sosial \\ Universitas Pendidikan Ganesha
}

\begin{abstract}
Abstrak
Secara naluriah manusia mendambakan Pemilu yang harmoni dan adil dalam kehidupan bermasyarakat dan bernegara. Tidak ada harmoni tanpa keadilan. Keadilan melahirkan harmoni, dan sebaliknya, harmoni mensyaratkan sekaligus memperkuat tumbuh suburnya keadilan. Namun, fenomena disharmoni dan ketidakadilan dalam Pemilu begitu sulit dihilangkan. Dominasi hawa nafsu terhadap akal, benturan kepentingan individu dan kelompok, kesenjangan sosial ekonomi, kepentingan politik, penegakan hukum diskriminatif, dan kepentingan nasional subyektif menjadi faktor penyebabnya. Civic virtue dapat menciptakan Pemilu yang harmoni dan berkeadilan. Sebagai ekspresi psikososialkultural warga negara, civic virtue mengandung karakter: berkeadaban, bertanggung jawab, integritas, disiplin, peka, terbuka, kompromi, toleran, sabar dan taat, murah hati dan empati, setia pada bangsa dan negara serta komitmen terhadap penegakan hukum dan hak asasi manusia.
\end{abstract}

Kata Kunci: Civic Virtue, Pemilu, Harmoni, dan Adil

\section{Abstract}

People instinctively crave an election that is harmony and fair in the life of society and the state. There is no harmony without justice. Justice breeds harmony, and vice versa, harmony requires while strengthening the flourishing of justice. However, the phenomenon of disharmony and injustice in the elections is so difficult to eliminate. The dominance of lust for reason, conflicting individual and group interests, socio-economic inequality, political interests, discriminatory law enforcement, and subjective national interests are the factors. Civic virtue can create elections that are harmonious and fair. As a psychosocial-cultural expression of citizens, civic virtue contains the character of: civilized, responsible, integrity, disciplined, sensitive, open, compromising, tolerant, patient and obedient, generous and empathetic, loyal to the nation and state and commitment to law enforcement and human rights.

Keywords: Civic Virtue, Election, Harmony and Fair

\section{Pendahuluan}

Pemilu kerap kali menimbulkan konflik, tidak hanya terjadi di Indonesia, bahkan konflik juga terjadi di luar negeri. CNN Indonesia (2019) mengungkapkan terdapat lima negara ricuh karena sengketa Pemilu, seperti di Venesuela pada saat pelantikan presiden Nicolas Maduro 
Volume 1, Nomor 2 Oktober 2019

ISSN : 2656-9639 (Cetak)

ISSN : 2684-9046 (Online)

tanggal 10 januari 2019 memicu krisis politik yang berkepanjangan, Pemilu 2014 di Afghanistan, Pemilu Juli 2018 di Pakistan, Pemilu bulan Juli 2018 di Zimbabwe dan Pemilu Desember 2018 di Kongo. Kerusuhan dan konflik itu tidak saja melibatkan warga negara dari masing-masing negara, melainkan telah meluas bahkan di duga diprakarsai oleh aktoraktor transnasional dan lembaga internasional. Meski telah menimbulkan banyak korban jiwa dan harta benda, tak seorangpun manusia bisa memastikan kapan dan bagaimana peristiwa itu akan berakhir.

Di Indonesia sendiri, kerusuhan dan konflik seakan tak pernah berhenti, begitu meresahkan dan menyengsarakan masyarakat. Pemilu yang berlangsung tanggal 17 April 2019 menyisakan konflik yang masih dapat dirasakan sampai saat ini. Ancaman yang terjadi sebelum dan setelah Pemilu berasal dari ancaman dunia nyata maupun dunia maya. Penyebaran hoaks yang masif, adu domba oleh sekelompok orang, hingga potensi serangan siber terhadap sistem yang dimiliki penyelenggara Pemilu menjadi beberapa ancaman yang terungkap. Benturan fisik yang terjadi pada aksi demonstrasi tanggal 22 mei 2019, merupakan peristiwa yang mencoreng demokrasi Indonesia, hal tersebut diduga telah terjadi penunggangan oleh segelintir elit politik yang merasa tidak menerima hasil dari Pemilu sehingga ia mencoba membuat ceos di masyarakat.

Makna yang dapat kita petik dari semua fenomena dan fakta sosial tersebut adalah hingga kini rasa "kedamaian" di se-antero dunia terus digerogoti oleh sikap dan perilaku "ketidakadilan" manusia khususnya dalam penyelenggaraan Pemilu. Jika demikian yang terjadi, apa yang mesti dilakukan? Kalaupun tidak bisa dihilangkan sama sekali, langkah apa yang patut diupayakan untuk menghambat laju pertumbuhan disharmoni dan ketidakadilan itu? Banyak hal yang mungkin bisa dilakukan, namun "roh"nya mesti berpijak pada bagaimana membangun dan menginternalisasikan "civic virtue" dalam kehidupan bermasyarakat, berbangsa, dan bernegara di dunia demokrasi saat ini? Apakah civic virtue dapat menciptakan dan memelihara harmoni sosial dan keadilan dalam Pemilu? Mengapa dan bagaimana civic virtue bisa mewujudkan Pemilu yang harmoni dan berkeadilan itu?

\section{Disharmoni dan Ketidakadilan dalam Pemilu: Mengapa Terjadi?}

Sederet contoh kasus yang digambarkan di atas menunjukkan bahwa fenomena ketidakadilan dan disharmoni dalam Pemilu merupakan bagian inhern kehidupan manusia. Dalam catatan sejarah, banyak konflik (perang) terjadi di masa lalu, seperti: konflik Sunni dan Syiah di Timur Tengah, konflik Arab-Israel, Konflik Uni Soviet-Afganistan, Perang Teluk, Perang Vietnam, Perang Dunia I dan Perang Dunia II, Perang Salib antara Islam dan Kristen, Perang Handak dan Perang Badar di zaman Rasulullah, Perang antara Fir ${ }^{\text {ee }}$ aun (bala tentaranya) dan Nabi Musa (pengikutnya), Perang antara Kaum Jahiliyah dan Nabi Ibrahim bersama pengikutnya. Yang tak kalah pentingnya untuk dikenang adalah "konflik perdana" di muka bumi: antara Qabil dan Habil ketika memperebutkan wanita sebagai pendamping. Semua fenomena kekerasan, konflik, dan perang tersebut merupakan satu bentuk ekspresi kejiwaan negatif manusia dalam meraih tuntutan dan kebutuhan hidup pribadi, bangsa dan negara.

Mengapa disharmorni dan ketidakadilan itu tampak menjadi bagian yang selalu eksis dalam kehidupan manusia, dulu hingga saat ini? Ada beberapa alasan: Pertama, secara naluriah, ada dua potensi yang dianugerahi Tuhan kepada manusia yaitu hawa nafsu dan 
Volume 1, Nomor 2 Oktober 2019

ISSN : 2656-9639 (Cetak)

ISSN : 2684-9046 (Online)

akal. Dalam pandangan Hindu, hawa nafsu (Kama) adalah bagian dari Sad Ripu yang harus dikendalikan oleh akal manusia itu sendiri. Hawa nafsu bersifat positif jika sudah terkendali atau hawa nafsu yang dikuasai oleh dharma (kebajikan), tidak masalah hawa nafsu itu besar atau kecil, asalkan terkendali oleh kebijaksanaan, maka hawa nafsu ini tergolong suatu hal yang baik dan benar. Sebaliknya, jika hawa nafsu menjadi suatu hal yang buruk jika hawa nafsu tersebut tidak terkendali oleh kebijaksanaan dan akal manusia. Hawa nafsu yang tidak terkendali inilah yang dimaksud menjadi bagian dari Sad Ripu, enam musuh tersembunyi yang ada pada setiap orang. Lima lainnya adalah kroda (emosi kemarahan), loba (ketamakan), moha (kebingungan), mada (kemabukan) dan matsarya (kedengkian). Hawa nafsu dan akal secara silih berganti berperan sebagai "lokomotif" dan "gerbong" dalam hidup manusia. Mengapa dan bagaimana itu terjadi?

Nafsu dan akal adalah dua makhluk yang saling berkompetisi memperebutkan jabatan dan kekuasaan untuk "merekayasa" manusia. Bagaimana potret kehidupan manusia seharihari sangat tergantung pada dominasi salah satu dari keduanya. Apabila akal mendominasi dan menjadi pemenang kompetisi, manusia tampil dengan "wajah" humanis, memiliki jiwa yang damai, konflik batin terkendali, nurani memancarkan kebenaran dan keadilan dalam sikap dan perilaku. Sebaliknya, apabila hawa nafsu merajai pertarungan dan berkuasa, disharmorni batin akan langgeng yang kemudian memancar dalam bentuk perilaku menyimpang manusia.

Perilaku korupsi dan berbagai bentuk abuse of power lainnya merupakan contoh konkrit. Pada hakekatnya, korupsi adalah satu bentuk pancaran kemenangan hawa nafsu pada diri seseorang dalam perseteruannya dengan akal. Hawa nafsu mengendalikan orientasi hidup pelaku korupsi sehingga mau menjarah hak-hak orang lain. Manusia menjadi rakus terhadap "asesoris" dunia, bertindak di luar batas kewajaran, mementingkan diri sendiri dan menempatkan materi (kebendaan) sebagai "panglima" dan target hidup. Kekuasaan dijadikan alat dan kesempatan untuk menumpuk harta dan kekayaan duniawi meskipun melibas rambu-rambu agama dan norma sosial. Itulah yang disebut Koentjaraningrat (1974) sebagai "budaya menerabas", atau "mentalitas penyerobot" (Sarwono, 2013:6), suatu sikap mental yang tidak memiliki tenggang rasa, tidak bisa ikut merasakan penderitaan orang lain, atau tidak ada empati. Ketika banyak penguasa "menerabas" atau "menyerobot", akan terjadi instabilitas sosial dan ketidakdilan global, sebab ada hak-hak yang tidak dinikmati si empunya. Gejolak sosial bermunculan, seperti: protes, demonstrasi, perusakan, hingga konflik bersifat destruktif, yang ujung-ujungnya menganggu rasa kedamaian masyarakat.

Alasan kedua, manusia adalah makhluk sosial yang memiliki hasrat dan kebutuhan beragam, dan kadang-kadang bertentangan satu sama lain. Pada satu sisi, manusia atau masyarakat lazim memenuhi kebutuhan sesuai kaidah yang berlaku. Pada tataran ini, kehidupan sosial masyarakat akan berlangsung secara harmonis. Namun pada sisi lain, seringkali ada seseorang atau sekelompok orang, dalam memperjuangkan kepentingan dan kebutuhan seringkali "menabrak" dan mengorbankan kepentingan orang atau kelompok lain. Sikap ambisi dan pragmatisme kelompok biasanya mengganggu ketentraman dan rasa keadilan kelompok lain. Pada titik inilah terjadi benturan di antara sesama anggota masyarakat sebab dirasakan ada pelanggaran hak.

Pemilu 2019 yang lalu telah terjadi beberapa kepentingan yang melegalkan berbagai cara untuk memenuhi hasrat dan kebutuhan sekolompok orang. Masyarakat Indonesia yang 
Volume 1, Nomor 2 Oktober 2019

ISSN : 2656-9639 (Cetak)

ISSN : 2684-9046 (Online)

selama ini dikenal sopan, santun, ramah dan penuh keadaban seperti mengalami perubahan. Sebagiannya terjebak ke dalam perilaku kekerasan dan bentuk-bentuk disharmoni lainnya. Sulit dinafikan bahwa nuansa panasnya politik dalam Pilpres 2019 berbeda dengan pilpres sebelumnya. Faktor utama kiranya bukan karena Pilpres 2019 langsung bersifat head to head, karena hal tersebut juga terjadi pada Pilpres 2014. Agaknya hal tersebut lebih didorong oleh faktor ketidakpuasan sebagian masyarakat terhadap sejumlah kebijakan yang dalam hal ini khususnya dirasakan oleh sebagian umat Islam. Isunya antara lain mulai dari dugaan penganiayaan ulama oleh orang gila dan kriminalisasi ulama. Isu dugaan banjirnya tenaga kerja asing (TKA) China ke Indonesia semakin memperkeruh suasana. Sehingga Pilpres pun marak diwarnai politisasi agama.

Pemilu pada dasarnya merupakan kontestasi pilihan. Oleh karena itu, perbedaan pilihan politik merupakan sebuah keniscayaan. Dengan pemilu rakyat diberi kesempatan untuk menilai calon yang dipandangnya lebih mampu untuk mewujudkan keadilan dan kemakmuran. Karenanya yang dibutuhkan dalam kampanye adalah tentang visi, misi, program dari masing-masing paslon pendukung capres/cawapres berikut kelebihan dan kekurangannya. Kritik dan saling adu argumentasi merupakan suatu hal yang niscaya. Dengan itu rakyat bisa lebih jernih dalam memilih calon pemimpinnya. Bukan saling hujat dan saling melempar ujaran kebencian, hoax, dan bentuk kampanye hitam. Peristiwa tersebut belakangan ini justru yang paling tampak dalam Pemilu. Nilai etika seolah tercerabut dari akar budaya politik yang ditanamkan leluhur dan para guru bangsa. Akibatnya, pemimpin yang terpilih merupakan pemimpin yang legitimasinya lebih didasarkan pada emosi dan perasaan, bukan pada kapabilitas, track record, dan kinerja.

Kesenjangan sosial ekonomi, kepentingan politik sektarian, dan penegakan hukum diskriminatif juga menjadi pemicu disharmoni dalam Pemilu. Ketimpangan ekonomi yang dilatarbelakangi oleh kebijakan (policy) negara yang keliru sehingga melahirkan kelompok miskin dalam jumlah besar seringkali menimbulkan kekecewaan, keresahan, radikalisme, hingga pembunuhan. Kebijakan pemerintah orde baru selama \pm 32 tahun telah menimbulkan kesenjangan luar biasa antara kawasan barat dan timur Indonesia. Meskipun diklaim bahwa saat ini terjadi penurunan angka kemiskinan, namun kesulitan banyak orang tua dalam menyekolahkan anak tidak bisa dipungkiri. Secara kasat mata, kemiskinan tergambar ketika banyak warga masyarakat berdesak-desakan berebut pembagian sembako gratis, yang kadangkala menimbulkan korban jiwa.

Aspek politik memainkan peran yang tak kalah pentingnya dalam menciptakan disharmoni dan ketidakdilan dalam masyarakat. Politik praktis apapun alasannya selalu berkaitan dengan bagaimana memenangkan pertarungan meraih dan mempertahankan kekuasaan (struggle for power) dalam sebuah negara. Kalaupun politik diterjemahkan sebagai upaya memperjuangkan kesejahteraan masyarakat atau kepentingan umum, namun tendensi itu harus selalu diselaraskan dengan kepentingan unit sosial atau politik tertentu, apakah bernama partai atau rezim. Proyek "golkarisasi" selama puluhan tahun yang berujung pada runtuhnya rezim orde baru, terbentuknya rezim Atut di Banten yang menimbulkan kecaman dan resistensi, serta maraknya isu putra daerah dalam Pilkada atau penerimaan pegawai merupakan sederet contoh kasus betapa dimensi politik sangat berkontribusi bagi tumbuh suburnya disharmoni dan ketidakadilan sosial. Karena itu, wajar apabila sebagian ilmuan memaknai politik sebagai konflik. 
Volume 1, Nomor 2 Oktober 2019

ISSN : 2656-9639 (Cetak)

ISSN : 2684-9046 (Online)

Kontribusi politik dimaksud makin berbahaya apabila berkorelasi dengan penegakan hukum diskriminatif. Lembaga penegak hukum sebagai sandaran keadilan seringkali melahirkan putusan "sarang semut" putusan yang menimbulkan reaksi negatif dan kebencian warga negara. Putusan sarang semut dilatarbelakangi oleh abuse of power aparat penegak hukum, seperti dilakukan mantan ketua Mahkamah Konstitusi Akil Mohtar. Demikian pula, penyalahgunaan dana simulator SIM Joko Susilo, kasus Hambalang, kasus suap Kajari Praya di NTB, serta banyak kasus hukum lainnya menimbulkan kebencian (resentment) di kalangan warga negara. Kasus-kasus itu secara langsung menurunkan tingkat kepercayaan publik terhadap lembaga penegak hukum dan pemerintahan. Ketika ketidakpercayaan berpadu dengan kebencian, maka gejolak sosial akan muncul yaitu demonstrasi dan anarkisme. Demonstrasi memperjuangkan "kepentingan rakyat" kemudian berhadapan dengan mobilisasi aparat demi "keamanan rakyat". Sekali lagi, disharmoni sosial diakibatkan oleh ketidakadilan hukum dan perilaku penegak hukum.

Hawa nafsu yang tak terkendali dan adanya hasrat untuk selalu memenangkan pertarungan meraih dan mempertahankan kekuasaan (struggle for power) dalam penyelenggaraan Pemilu telah melahirkan ketidakadilan dan disharmoni di masyarakat. Politik Praktis, money politik, abuse of power, dan KKN kerap kali terjadi disetiap penyelenggaraan Pemilu yang menimbulkan dampak pada terjadinya disharmoni hubungan antar warga negara dan Pemilu yang tidak mencerminkan asas LUBER JURDIL. Pertanyaannya kemudian, bagaimana mengatasinya? Adakah langkah-langkah efektif, praktis, dan visioner dalam menopang terwujudnya suatu tatanan masyarakat yang harmonis dan berkeadilan? Salah satu solusinya adalah melalui implementasi civic virtue dalam kehidupan sosial dan bernegara.

\section{Civic Virtue: Solusi Mewujudkan Pemilu Harmoni dan Berkeadilan}

Salah satu di antara tiga misi pendidikan kewarganegaraan dalam rangka mewujudkan masyarakat madani, menurut Winataputra (2001), adalah misi substantif- akademis. Misi ini berkaitan dengan pengembangan struktur atau tubuh pengetahuan pendidikan kewarganegaraan, termasuk di dalamnya konsep, prinsip, dan generalisasi mengenai dan yang berkenaan dengan civic virtue (kebajikan kewarganegaraan), dan civic culture (budaya kewarganegaraan) melalui kegiatan penelitian dan pengembangan (fungsi epistemologis) dan memfasilitasi praksis sosio-pedagogis dan sosio-kultural dengan hasil penelitian dan pengembangannya itu (fungsi aksiologis). Misi ini antara lain menempatkan civic virtue sebagai pilar yang mesti dikembangkan untuk mewujudkan masyarakat madani. Asumsinya bahwa masyarakat madani dicirikan oleh kesatuan pribadi warganegara yang memiliki kebajikan kewarganegaraan (civic virtue). Kalau demikian adanya, apa sebenarnya esensi civic virtue itu?

Istilah virtue (kebajikan), lazim dikaitkan dengan posisi dan peran manusia sebagai makhluk individu dan makhluk sosial. Montesquieu, sebagaimana dikutip Quigley dan Bahmueller (1991:11) menyatakan bahwa virtue is the principle of republican government... Virtue in a republic is love of one's country, that is, love of equality. It is not a moral virtue, not a Christian, but a public virtue. Ini mengandung pengertian bahwa kebajikan berkaitan dengan prinsip dan pemerintahan republik. Kebajikan dalam republik adalah cinta terhadap negerinya, cinta persamaan atau kesetaraan. Kebajikan bukanlah suatu kebajikan moral, 
Volume 1, Nomor 2 Oktober 2019

ISSN : 2656-9639 (Cetak)

ISSN : 2684-9046 (Online)

bukan kebajikan Kristiani, akan tetapi kebajikan publik. Dari definisi ini tampak bahwa Montesquieu ingin menekankan pengertian virtue sebagai nilai-nilai positif yang bersumber dari kehendak dan kesepakatan bersama. Secara implisit berarti, apa yang dikehendaki dan diputuskan secara kolektif demi kepentingan dan kebaikan bersama dalam satu kesatuan politik, itulah kebajikan.

Gagasan Montesquieu tentang virtue sebagai kebajikan publik, kemudian dikembangkan Quigley sebagai urusan publik dan pribadi warga negara. Menurut Quigley, sebagaimana dikutip Winataputra (2012:58-59), civic virtue adalah kemauan dari warga negara untuk menempatkan kepentingan umum di atas kepentingan pribadi. Civic virtue merupakan domain psikososial indvidu yang secara substantif memiliki dua unsur, yaitu civic dispositions dan civic commitments. Civic dispositions adalah sikap dan kebiasaan berpikir warga negara yang menopang berkembangnya fungsi sosial yang sehat dan jaminan kepentingan umum dari sistem demokrasi. Sedangkan civic commitments adalah komitmen warga negara yang bernalar dan diterima dengan sadar terhadap nilai dan prinsip demokrasi konstitusional.

Lebih lanjut dikatakan, civic dispositions berkaitan dengan sejumlah karakteristik kepribadian seseorang warga negara, berupa: civility atau keadaban (hormat pada orang lain dan partisipatif dalam kehidupan masyarakat), individual responsibility atau tanggung jawab individual, self-discipline atau disiplin diri, civic- mindedness atau kepekaan terhadap masalah kewargaan, open-mindedness (terbuka, skeptis, mengenal ambiguitas), compromise (prinsip konflik dan batas-batas kompromi), toleration of diversity atau toleransi atas keberagaman, patience and persistence atau kesabaran dan ketaatan, compassion atau keterharuan, generosity atau kemurahan hati, dan loyalty to the nation and its principles atau kesetiaan pada bangsa dan segala aturannya. Sedangkan civic commitments adalah kesedian warga negara untuk mengikatkan diri dengan sadar kepada ide dan prinsip serta nilai fundamental demokrasi konstitusional.

Menurut Quigley (1991), kebajikan kewarganegaraan (civic virtue) terdiri dan ciri-ciri dan karakter, disposisi, dan komitmen yang penting bagi pemeliharaan dan perbaikan pemerintahan dan kewarganegaraan demokratis. Contoh-contoh dan kebajikan-kebajikan kewarganegaraan adalah tanggung jawab individu, disiplin diri, integritas, patriotisme, toleransi dalam keragaman, kesabaran dan konsistensi, dan rasa kasihan untuk yang lain. Komitmen-komitmen tersebut, termasuk pengabdian terhadap hak azasi manusia, persamaan, kebaikan umum, dan aturan hukum.

Senada dengan Quigley, Bray dan Larry (2005:86) mengatakan, civic virtues are the qualities of character and personal skills necessary to make the exercise of citizenship meaningful. Civic virtues give us the capacity to exercise our rights, promote our interests and meet our duties. Ini mengandung pengertian bahwa kebajikan-kebajikan kewarganegaraan adalah kualitas dari karakter dan ketrampilan- ketrampilan pribadi yang diperlukan untuk kebermaknaan latihan kewarganegaraan. Kebajikan-kebajikan kewarganegaraan memberikan kepada kita kapasitas untuk berlatih hak-hak kita, mempromosikan minat dan kewajiban-kewajiban kita.

Dari uraian di atas tampak bahwa melalui internalisasi civic virtue akan lahir suatu sikap dan perilaku kewarganegaraan yang baik dari seorang warga negara, baik sebagai makhluk sosial, abdi negara, maupun sebagai warga dunia (global citizen). Civic virtue akan 
Volume 1, Nomor 2 Oktober 2019

ISSN : 2656-9639 (Cetak)

ISSN : 2684-9046 (Online)

membentuk jiwa yang mau dan mampu menghormati orang lain (keadaban), mempunyai kedisiplinan dan rasa tanggung jawab selaku warga negara (self-discipline and responsibility), peka dan empati terhadap masalah kemanusiaan dan kewargaan, terbuka dan toleran terhadap keberagaman, patuh dan sabar terhadap ketentuan negara. Ini merupakan esensi dari pemenuhan hak dan kewajiban selaku warga negara, dalam kerangka membentuk warga negara yang cerdas dan baik (smart and good citizen). Bila sejumlah watak itu terpatri dan menjelma dalam pribadi warga negara dan pemimpin bangsa, maka bukan saja hubungan warga negara dengan negara semakin baik, akan tetapi juga hubungan antar negara dalam pergaulan internasional makin harmonis dan berkeadilan. Suatu negara yang baik dalam pergaulan internasional antara lain ditentukan oleh sejauhmana pemimpin dan warga negara memiliki akhlak kewarganegaraan (civic virtue) sebagai fondasi membangun kepercayaan (trust) satu sama lain.

Winataputra (2012:60) menjelaskan, bahwa: "sasaran pengembangan civic virtue dan civic participation adalah untuk mengembangkan watak dan karakter warga negara yang peka, tanggap, dan bertanggungjawab terhadap masyarakat, bangsa, dan negaranya...Civic virtue atau kebajikan atau akhlak kewarganegaraan mencakup keterlibatan aktif warga negara, hubungan kesejajaran/egaliter, saling percaya dan toleran, kehidupan yang kooperatif, solidaritas, dan semangat kemasyarakatan ${ }^{\text {ee }}$. Semua unsur akhlak kewarganegaraan itu diyakini saling memupuk dengan kehidupan civic community atau civil society atau masyarakat madani Indonesia. Dengan kata lain, tumbuh dan berkembangnya masyarakat madani bersifat interaktif dengan tumbuh dan berkembangnya akhlak kewarganegaraan (civic virtue) yang merupakan unsur utama dari budaya kewarganegaraan (civic culture)".

Apabila tiap warga negara dan pemimpin bangsa menginternalisasikan akhlak kewarganegaraan dimaksud, maka sikap dan perilaku akan memancarkan nilai-nilai kedamaian dan keadilan. Hal itu merupakan nilai-nilai yang bersifat universal, sebab setiap manusia dimanapun berada, secara obyektif pasti menghendaki kedamaian dan keadilan, meskipun secara subyektif belum tentu mau dan mampu mewujudkannya. Hasil penelitian Peterson dan Seligman (2004:36) menemukan bahwa keadilan (justice) merupakan salah satu di antara enam nilai kebajikan universal yang melekat pada tradisi sosial atau budaya masyarakat global, seperti di Cina, Asia Selatan, dan negara-negara Barat. Dikatakan bahwa di negara-negara industri Barat, keadilan umumnya diterjemahkan ke dalam gagasan kesetaraan, yaitu keyakinan bahwa ganjaran harus dibagi secara adil menurut kontribusi atau keuntungan, dan bahwa orang-orang pada akhirnya memperoleh apa yang mereka layak dapatkan.

Salah satu bentuk kebajikan warga negara sekaligus pemimpin bangsa adalah apa yang ditunjukkan almarhum Nelson Mandela. Ketika berkuasa (menjadi Presiden Afrika Selatan), ia tidak melakukan pembalasan (revenge) kepada para pelaku kejahatan kemanusiaan terhadap dirinya di masa lalu (ketika politik Apartheid berlangsung), bahkan justru memberikan pemaafan (forgiven). Menurut Azra (2013:6), sikap "memaafkan meski tidak melupakan" yang ditunjukkan Mandela merupakan suatu kebajikan tingkat tinggi, yang walaupun semua agama dan nilai luhur mengajarkan tapi tidak sanggup dilakukan semua orang. Mandela telah memberikan warisan kebajikan kewarganegaraan mulia yang mestinya bisa ditiru oleh bangsa Indonesia. Menurut hemat penulis, di tengah degradasi kepercayaan 
publik terhadap lembaga-lembaga pemerintahan saat ini, figur dan akhlak kewarganegaraan Mandela tetap dimiliki bangsa Indonesia sepanjang masa, bahkan boleh jadi melebihi keluhuran budi seorang Mandela, meskipun dalam jumlah yang sangat terbatas. Bangsa ini pernah memiliki Baharuddin Lopa seorang hakim dan pimpinan lembaga peradilan yang memiliki integritas dan komitmen tinggi dalam penegakan hukum dan HAM, masih ada sosok Artidjo Al-Kotsar seorang hakim Mahkamah Agung yang memberikan hukuman sangat berat terhadap pelaku kejahatan kemanusiaan (koruptor), dan masih ada Dr. I Dewa Gede Palguna, S.H.,M.Hum yang merupakan hakim MK yang memutuskan hasil perkara sidang sengketa Pemilu 2019. Selain itu pula Palguna juga dikenal sebagai sosok yang memiliki komitmen dalam penegakan demokrasi dan prinsip rule of law, menurutnya "mungkin benar bahwa tanpa demokrasi dan rule of law suatu bangsa bisa menikmati kemakmuran, tetapi adalah juga benar bahwa tanpa demokrasi dan rule of law suatu bangsa sudah pasti tidak menikmati keadilan".

Dalam kehidupan bernegara, internalisasi civic virtue bagi setiap warga negara dirasakan begitu penting dan mendesak sebagai pilar penyanggah dampak globalisasi. Melalui pendidikan kewarganegaraan, civic virtue ditanamkan secara efektif kepada siswa selaku warga negara muda (young citizen). Sinergi pembelajaran yang efektif, kreatif, dan menyenangkan antara guru dan siswa harus terbangun sedemikian rupa sehingga menghasilkan output pembelajaran yang mampu menggugah, menanamkan, dan mempraktikkan kebajikan kewarganegaraan itu dalam perilaku sehari-hari. Karena itu, kebajikan warga negara harus dikembangkan melalui kegiatan-kegiatan belajar, menggunakan buku sumber, mempelajarinya secara aktif, serta menghubungkan antara isi dan proses dalam membelajarkan pengetahuan, ketrampilan dan kebajikan- kebajikan warga negara (Azis Wahab, 2006).

Dalam konteks Indonesia, dengan menginternalisasikan civic virtue kepada setiap warga negara (termasuk peserta didik) diyakini dapat mengatasi ancaman disintegrasi bangsa berupa: primordialisme, sentralisme, dan social injustice, dan menekan semaksimal mungkin terjadinya apa yang Azis Wahab (2010) sebut sebagai "disorientasi bangsa", seperti: arogansi kekuasaan, materialisme, hedonisme, konsumerisme, destruktivisme, vandalisme, feodalisme, primordialisme, irresponsible, dan nepotisme.

Dengan demikian, sebagai gerakan psikososial-kultural, civic virtue dapat menciptakan harmoni dalam masyarakat, membangun kesetaraan, menutup ruang terjadinya "tabrakan" hak sehingga bisa mewujudkan keadilan bagi semua pihak. Membangun harmoni dan keadilan bukan hanya tanggung jawab negara, melainkan tugas dan tanggung jawab setiap warga negara. Dalam kehidupan sehari-hari, harmoni sosial bisa terwujud apabila setiap individu mau "membumi", menengok keadaan sosialnya, menyapa tetangga, dan ikut hadir dalam berbagai kegiatan kewargaan (Yunus, 2013). Pada akhirnya, kebajikan kewarganegaraan yang tumbuh pada diri setiap pribadi dapat menciptakan suasana kehidupan masyarakat yang penuh toleran, tenggang rasa, dan harmonis.

\section{Penutup}

Harmoni dan keadilan merupakan dambaan setiap orang, hak dasar setiap pribadi warga negara yang harus ditunaikan secara konsisten. Harmoni bisa terwujud apabila ada keadilan substantif dan prosedural dalam masyarakat atau negara. Bila tidak, maka yang muncul 
Volume 1, Nomor 2 Oktober 2019

ISSN : 2656-9639 (Cetak)

ISSN : 2684-9046 (Online)

adalah pertentangan, kekerasan, konflik, bahkan peperangan yang menimbulkan malapetaka bagi manusia. Masyarakat yang harmonis tidak selalu berarti tidak ada pertentangan di dalamnya, melainkan masyarakat yang mampu mengelola pertentangan itu secara bijak, yang menguntungkan semua pihak sehingga tidak berujung pada perpecahan dan konflik. Tidak ada harmoni tanpa keadilan. Keadilan melahirkan harmoni, dan sebaliknya, harmoni mensyaratkan sekaligus memperkuat tumbuhsuburnya keadilan. Keadilan sejati ditandai bila tidak ada lagi rumah kumuh di tengah hamparan bangunan megah dan rumah mewah, tidak ada lagi kelaparan dan gizi buruk di tengah limpahan materi dan kemewahan penjahat krah putih, tidak terusik lagi rasa keadilan hukum masyarakat di tangan para pemutus perkara, serta tidak ada lagi keresahan dan kegelisahan warga negara di tengah kekayaan dan kemesraan penguasa yang zalim. Keadilan tidak berarti selalu sama, melainkan proporsional dan seimbang dalam memperoleh hak-hak (rights) dan menunaikan kewajiban (duties). Hal itu bisa diwujudkan apabila semua komponen bangsa dan negara di permukaan bumi ini memiliki civic virtue - suatu ekspresi psikososial-kultural yang mengandung sense of crisis, empati, amanah, penuh integritas dan dedikasi dalam mewujudkan bangsa dan negara yang amar ma'ruf nahi munkar menuju terciptanya masyarakat yang baldatun toyyibatun warabbun gafur.

\section{Daftar Pustaka}

Azra, Azyumardi. 2013. "Warisan Mandela". dalam Harian Kompas, edisi Sabtu, 7 Desember.

Bray, Bernard L. dan Larry, Chappel W. 2005. "Civic Theater for Civic Education". dalam Journal of Political Science Education. Volume 1, Number 1, 2005 (p.83-108).

CNN. 2019. Lima Negara Ricuh karena Sengketa Pemilu. https:/www.cnnindonesia.com/internasional/ 20190521112908-106-396803/limanegara-ricuh-karena-sengketa-pemilu. (diakses: tanggal 17 September 2019)

Koentjaraningrat. 1974. Kebudayaan, Mentalitas dan Pembangunan. Jakarta: Gramedia.

Peterson, C., dan Seligman, M.E.P., 2004. Character Strengths and Virtues: a Handbook and Classification. New York: Oxpord University Press.

Quigley, Charles N and Charles F. Bahmueller. 1991. Civitas: A Framework for Civic Education. Calabasas: Center for Civic Education.

Sarwono, Sarlito, W. 2013. "Mentalitas Penyerobot". dalam Harian Kompas, edisi 11 Desember.

Wahab, A. A. 2006. Pengembangan Konsep dan Paradigma Pendidikan Kewarganegaraan Baru Indonesia bagi Terbinanya Warganegara Multidimensional Indonesia. Dalam: D. Budimansyah dan S. Syam (Penyunting). Pendidikan Nilai Moral Dalam Dimensi Pendidikan Kewarganegaraan. Bandung: Laboratorium PKn UPI

Wahab, A. A. 2010. Memantapkan Kembali Jatidiri Bangsa dalam Kerangka Penguatan Dasar-Dasar Pendidikan Kewarganegaraan Indonesia. Dalam: K. Komalasari (Penyunting). Building Civic Competences in Global Era Through Civic Education: Problem and Prospect. Bandung: Laboratorium PKn UPI.

Winataputra, Udin S. 2001. "Jatidiri Pendidikan Kewarganegaraan Sebagai Wahana Sistemik Pendidikan Demokrasi”. Disertasi. Bandung PPs UPI. Tidak Diterbitkan.

Winataputra, Udin S. 2012. Pendidikan Kewarganegaraan Dalam Perspektif Pendidikan 
Volume 1, Nomor 2 Oktober 2019

ISSN : 2656-9639 (Cetak)

ISSN : 2684-9046 (Online)

Untuk Mencerdasakan Kehidupan Bangsa (Gagasan, Instrumentasi, dan Praksis). Bandung: Widya Aksara Press.

Yunus, Syarif. 2013. "Merajut Harmoni Sosial \& Kerukunan Bertetangga di Komunitas Edelweiss (KOMED) Harvest City". http://lifestyle.kompasiana.com/catatan/ 2013/01/24/html. (diakses 17 September 2019) 